\title{
ELEMENT OF POLITENESS IN INTERCULTURAL COMMUNICATION: THE CASE STUDY OF JAPANESE AND MALAYSIAN TOURISTS ${ }^{1}$
}

\author{
Roslina Mamat ${ }^{2}$, Roswati Abdul Rashid ${ }^{3}$,dan Rokiah Paee ${ }^{4}$
}

\begin{abstract}
The number of Japanese tourists visiting Malaysia has consistently ranked in the top ten over the last 20 years, whereas Japan has been the country of choice for Malaysian tourists for the last ten years. It is, therefore, crucial that tourism communication in the cross-cultural context between Malaysia and Japan is used as a reference to improve the cross-cultural communication skills of the tourism employees involved. This article discusses the external structure of Japanese conversation between native Japanese speakers and Malaysian tourist guides and native Malay speakers with Japanese tourist guides. This study is qualitative and uses the discourse analysis approach. A total of four conversation sessions in the form of Free Independent Travel (FIT) tourism were held in Malacca and Tokyo. The conversations were recorded, and the researchers also made notes throughout the conversation to see the sentence structures and non-linguistic elements to complete the data. The recording was then transcribed and encoded before being analysed. Only the conversations by tourist guides were analysed and included in the contents of this article as the focus of the study is more on the external form and politeness of the Japanese language used by Malaysian and Japanese tourist guides in demonstrating solidarity and similarities in the context of cross-cultural conversation. Data analysis shows many similarities in the selection of vocabulary and specific verb forms by Japanese and Malaysian tourist guides to show courtesy and friendliness in the conversation. This proves that Japanese language skills by Malaysian tourist guides are almost on par with Japanese tourist guides. Malaysian tourist guides also have a vast knowledge of the culture and nature of the Japanese language.
\end{abstract}

Keywords: cross-cultural communication, Japanese tourists, politeness in conversation, Malaysian tourist guide, language skills.

\footnotetext{
${ }^{1}$ Sejarah artikel: Tarikh penghantaran ke jurnal: 22 Jun 2021; Tarikh diluluskan: 17 September 2021; Tarikh diterbitkan: 15 Disember 2021.

${ }^{2}$ Penulis Pertama dan Penghubung: Profesor Madya Dr. Roslina Mamat, Jabatan Bahasa Asing, Fakulti Bahasa Moden dan Komunikasi, Universiti Putra Malaysia (UPM), Serdang, Selangor, Malaysia. Email: linamm@upm.edu.my

${ }^{3}$ Penulis Kedua: Dr. Roswati Abdul Rashid, Pensyarah Kanan, Jabatan Bahasa dan Komunikasi, Pusat Pendidikan Asas dan Berterusan, Universiti Malaysia Terengganu (UMT), Kuala Nerus, Terengganu, Malaysia. Email: roswati@umt.edu.my

${ }^{4}$ Penulis Ketiga: Dr. Rokiah Paee, Pensyarah Kanan dan Penyelaras Kursus, Fakulti Bahasa dan Komunikasi, Universiti Malaysia Sarawak (UNIMAS), Kota Samarahan, Sarawak, Malaysia. Email: prokiah@unimas.my
} 


\title{
ELEMEN KESOPANAN DALAM KOMUNIKASI ANTARA BUDAYA: KAJIAN KES TERHADAP PELANCONG JEPUN DAN MALAYSIA
}

\begin{abstract}
Abstrak: Kedatangan pelancong Jepun ke Malaysia sentiasa menduduki carta sepuluh teratas dalam tempoh 20 tahun kebelakangan. Manakala Jepun pula dalam tempoh 10 tahun adalah negara pilihan rakyat Malaysia berbanding negara lain. Oleh itu adalah penting komunikasi pelancongan dalam konteks silang budaya antara Malaysia dan Jepun dibuat perbandingan sebagai rujukan demi meningkatkan kemahiran komunikasi silang budaya para pekerja pelancongan yang terlibat. Artikel kerja ini membincangkan struktur luaran perbualan bahasa Jepun antara penutur asli bahasa Jepun dengan pemandu pelancong Malaysia dan penutur asli bahasa Melayu bersama pemandu pelancong Jepun. Kajian ini bersifat kualitatif dengan menggunakan pendekatan analisis wacana. Sebanyak empat sesi perbualan dalam pelancongan berbentuk Free Independent Travel (FIT) telah dilakukan di Melaka dan Tokyo. Perbualan telah dirakam dan penyelidik juga telah membuat catatan sepanjang perbualan bagi melihat struktur ayat dan elemen bukan linguistik bagi melengkapkan data. Rakaman ini kemudian dibuat transkripsi dan dikod sebelum dianalisis. Hanya perbualan oleh pemandu pelancong yang dianalisis dan dimuat dalam kandungan kertas kerja ini kerana fokus kajian lebih kepada bentuk luaran dan kesopanan bahasa Jepun yang digunakan oleh pemandu pelancong Malaysia dan Jepun dalam menunjukkan solidariti dan persamaan dalam konteks perbualan silang budaya. Analisis data menunjukkan terdapat banyak persamaan dalam pemilihan kosakata dan bentuk kata kerja tertentu oleh pemandu pelancong Jepun dan Malaysia bagi menunjukkan kesopanan dan kemesraan dalam perbualan. Hal ini membuktikan bahawa kemahiran bahasa Jepun oleh pemandu pelancong Malaysia adalah hampir setara dengan pemandu pelancong Jepun. Pemandu pelancong Malaysia juga mempunyai pengetahuan luas dalam budaya dan sifat bahasa Jepun.
\end{abstract}

Kata Kunci: komunikasi silang budaya, pelancong Jepun, kesopanan dalam perbualan, pemandu pelancong Malaysia, kemahiran bahasa.

\section{PENGENALAN}

Komunikasi merupakan perkara asas dalam kehidupan manusia bagi menyampaikan maklumat dan kehendak individu, organisasi awam dan swasta. Seiring perubahan masa, komunikasi menjadi lebih luas dengan melibatkan ramai pihak. Pada zaman awal, manusia digambarkan hanya mempunyai cara komunikasi yang mudah dan menggunakan bahasa isyarat kerana keterbatasan kod bahasa yang dicipta pada zaman itu. Kini adanya sistem komunikasi yang semakin canggih, kepelbagaian media sosial serta dunia yang semakin maju, terbuka dan mudah diterokai menjadikan mesej dan maklumat cepat dan mudah sampai kepada penerima sasaran. Komunikasi dua hala tidak lagi melibatkan hanya penutur dengan pendengar atau penulis dengan pembaca tetapi melibatkan syarikat telekomunikasi atau penterjemah. Pelancong masih lagi menggunakan khidmat pemandu pelancong, kamus atau aplikasi tertentu bagi memudahkan perjalanan atau mencari maklumat mengenai sesuatu lokasi atau produk pelancongan. Walau bagaimanapun mungkin dalam jangka masa yang singkat, pelancong tidak lagi 
memerlukan pemandu pelancong atau penterjemah dengan kewujudan berbagai-bagai aplikasi dalam talian melalui telefon pintar.

Dengan berlakunya Revolusi Industri Ke-4 (Industrial Revolution (IR 4.0), dikatakan bahawa manusia tidak perlu lagi mempelajari bahasa asing untuk tujuan pelancongan kerana kini alat yang boleh menterjemah dokumen bertulis atau pertuturan manusia telah berada di pasaran. Pada masa kini kualiti penterjemahan dan interpretasi masih belum mencapai standard yang diperlukan tetapi setiap tahun produk yang dihasilkan sentiasa dikemaskini dan ditambah baik. Walau bagaimana industri pelancongan berkembang, dari khidmat pemandu pelancong kepada penggunaan alat atau aplikasi sudah tentu elemen budaya yang wujud dalam pertuturan manusia tidak dapat digantikan dengan mudah oleh teknologi moden. Ini kerana dalam setiap bahasa terdapat elemen budaya yang tidak boleh diterjemahkan sekadar menggunakan kamus atau terjemahan dalam talian. Ujaran seperti ' $h a i$ ' atau 'naruhodo' dalam bahasa Jepun sudah tentu tidak boleh diterjemahkan sekadar menggunakan terjemahan literal 'yes' atau 'I see' kerana ujaran itu boleh membawa maksud yang taksa. Ayat yang mengandungi ujaran tersebut, malah ujaran sebelum dan selepas ayat tersebut turut perlu diberi perhatian bagi mencari makna yang sebenar. Oleh itu bidang kajian pragmatik dan analisis wacana menjadi penting bagi mencari makna yang tersurat dan tersirat. Kajian ini akan membuktikan bahawa komunikasi antara budaya adalah sesuatu yang tidak mudah dan khidmat pemandu pelancong masih relevan dalam komunikasi terutama jika melibatkan interaksi dua hala.

Kajian perbandingan dilakukan ke atas perbualan dalam sesi pelancongan ini menggunakan pendekatan analisis wacana bagi melihat struktur luaran perbualan bahasa Jepun antara penutur asli bahasa Jepun dengan pemandu pelancong Malaysia dan penutur asli bahasa Melayu bersama pemandu pelancong Jepun. Kedua-dua set perbualan antara budaya ini menggunakan bahasa Jepun. Dengan cara ini penyelidik akan dapat melihat bagaimana pemandu pelancong Melayu menyesuaikan struktur linguistik dan bukan linguistik bahasa Jepun bagi mencapai matlamat komunikasi bersama pelancong Jepun. Begitu juga penyelidik akan dapat melihat bagaimana pemandu pelancong Jepun menggunakan struktur linguistik dan bukan linguistik bahasa Jepun bagi mencapai matlamat komunikasi bersama pelancong Melayu. Objektif kajian ini adalah membandingkan penggunaan fitur kesopanan bahasa Jepun oleh pemandu pelancong Jepun dan pemandu pelancong Malaysia.

\section{LATAR BELAKANG KAJIAN}

Belum ada penyelidikan yang dilakukan oleh pengkaji tempatan sebelum ini terhadap analisis perbualan bahasa Jepun yang menyentuh mengenai fitur kesopanan dalam perbualan antara pemandu pelancong dan pelancong dalam bahasa Jepun kecuali Roslina Mamat ${ }^{5}$ dan Roswati Abdul Rashid ${ }^{6}$. Roslina Mamat adalah penyelidik bahasa Jepun pertama yang mengkaji analisis perbualan bahasa Jepun sejak tahun 2004, manakala Roswati Abdul Rashid pula mengkhusus kepada interaksi dua hala antara pemandu pelancong dan pelancong yang menggunakan bahasa Jepun. Oleh itu, dalam bahagian ini penulis membincangkan perkembangan analisis wacana sejak awal sehingga kini, bagi membolehkan penyelidik baharu yang berminat dalam bidang analisis wacana dapat memahami dengan lebih mudah.

\section{Analisis wacana}

Wacana juga boleh dibahagikan kepada dua kategori iaitu wacana terancang dan wacana tidak terancang. Contoh wacana penulisan terancang adalah teks ucapan pemimpin, berita dalam akhbar harian sama ada akhbar fizikal atau dalam talian. Manakala contoh wacana penulisan tidak terancang adalah seperti teks perbualan dalam Whatsapp, nota kuliah dan Instagram. Ucapan pemimpin sama

\footnotetext{
${ }^{5}$ Bidang penyelidikan Prof. Madya Dr. Roslina Mamat adalah analisis perbualan bahasa Jepun dan budaya popular Jepun ${ }^{6}$ Bidang penyelidikan Dr. Roswati Abdul Rashid adalah kesopanan dalam perbualan bahasa Jepun dalam interaksi pemandu pelancong tempatan dan pelancong Jepun.
} 
ada Perdana Menteri atau menteri termasuk dalam wacana perbualan terancang kerana pemimpin membuat ucapan berdasarkan teks. Jika dalam sesi soal-jawab, pemimpin tersebut tidak merujuk kepada teks atau merujuk kepada teks sekadar menyemak fakta, ucapan tersebut adalah termasuk dalam wacana tidak terancang kerana ia berlaku secara spontan. Perbualan antara doktor dan pesakit, mesyuarat dan perbualan kosong sudah pasti termasuk dalam kategori wacana perbualan atau pertuturan tidak terancang.

Pengkaji analisis perbualan tidak mengkaji nahu ayat sama ada ia benar dari segi hukum linguistik dan sebagainya tetapi mengkaji pengambilan giliran, jeda, pertindanan, celahan, kuasa dalam perbualan, latar belakang peserta perbualan dan sebagainya yang bersangkutan peserta perbualan dan ujaran yang terhasil. Sudah pasti kesopanan, sifat bahasa, budaya dan nilai peserta turut diambil kira semasa menganalisis data kerana bahasa bersifat dinamik yang sentiasa berubah mengikut arus zaman dan lokasi ia dituturkan. Analisis perbualan adalah kajian terhadap perbualan yang dirakam, dibuat transkripsi, dan diberikan simbol tertentu termasuk unsur bukan linguistik seperti celahan, pertindanan, ketawa dan sebagainya. Ini bagi membolehkan pengkaji lain yang tidak berada dalam situasi perbualan tersebut turut memahami teks dan latar belakang perbualan. Sacks, Schegloff dan Jefferson ${ }^{7}$ adalah pengkaji perintis bagi analisis perbualan yang mendapat inspirasi daripada Garfinkel, seorang ahli sosiologi dan etnometodologi Amerika Syarikat dan Goffman, seorang sosiologis dan psikologis terkemuka di Amerika Syarikat. Teori dan pendekatan Sacks et. al. masih relevan sehingga kini, walaupun terdapat pengkaji lain selepasnya seperti Gumperz seorang linguis terkemuka.

Sebenarnya, kajian perbualan dalam bahasa Melayu di Malaysia sangat jarang dilakukan oleh pengkaji tempatan apatah lagi kajian perbualan dalam bahasa asing, terutama bahasa Jepun. Walau bagaimanapun, kajian perbualan dalam bahasa Inggeris kerap dilakukan kerana bahasa Inggeris merupakan bahasa kedua Malaysia (atau bahasa pertama bagi sesetengah rakyat), yang secara umumnya digunakan oleh semua kaum di Malaysia kecuali di kawasan luar bandar. Kajian tentang perbualan bahasa Cina dan Tamil juga kurang dijalankan walaupun kaum Cina dan India merupakan dua kaum terbesar setelah kaum Melayu. Pengkaji tempatan pertama yang membuat kajian analisis wacana dalam perbualan bahasa Jepun oleh penutur asli dipelopori oleh Roslina Mamat ${ }^{8}$. Kajiannya adalah tentang sistem pengambilan giliran dan aizuchi (maklum balas minimal) dalam perbualan oleh pemimpin parti politik Jepun dalam siri diskusi Nihon Housou Kyoukai (NHK), Jepun. Kajian beliau yang seterusnya adalah analisis perbualan oleh pemandu pelancong Malaysia dan pelancong Jepun dalam Roslina Mamat, Normaliza Abdul Rahim, Hazlina Abdul Halim dan Farah Tajuddin ${ }^{9}$. Roswati Abdul Rashid et.al. ${ }^{10}$ pula telah mengkaji strategi komunikasi dan aspek kesopanan dalam perbualan antara pemandu pelancong Malaysia dan pelancong Jepun. Selain Roslina Mamat dan Roswati Abdul Rashid, tiada lagi pengkaji tempatan yang membuat kajian tentang analisis perbualan bahasa Jepun dalam sesi pelancongan. Oleh itu dalam artikel ini, hanya kajian literatur dari mereka berdua sahaja yang dapat dimasukkan sebagai mewakili pengkaji tempatan yang mengkhusus dalam analisis perbualan bahasa Jepun oleh pemandu pelancong.

\footnotetext{
${ }^{7}$ Harvey Sacks, Emanual Schegloff, and Gail Jefferson, “A Simplest Systematic for the Organization of Turn-Taking for Conversation," Language 50, no. 4, (1974): 696-735.

${ }^{8}$ Roslina Mamat, “Analisis Perbualan Penutur Asli Bahasa Jepun: Satu Kajian Pengambilan Giliran dan Aizuchi” (Tesis PhD, Universiti Malaya, 2004).

${ }^{9}$ Roslina Mamat, Normaliza Abdul Rahim, Hazlina Abdul Halim dan Farah Tajuddin, "Short Utterances in Japanese Language Conversation among Japanese and Malaysian Tourist Guides," Jurnal Komunikasi: Malaysian Journal of Communication 28, no. 1, (2012): 97-106.

${ }^{10}$ Roswati Abdul Rashid, "Strategi Komunikasi Bahasa Jepun dalam Konteks Antara Budaya Semasa Sesi Lawatan Pemanduan Pelancongan di Malaysia” (Tesis PhD, Universiti Putra Malaysia, 2015).
} 
Pengkaji luar negara seperti Haugh ${ }^{11}$ mengkaji kata hubung yang terdapat dalam ujaran akhir, manakala Saft ${ }^{12}$ mengkaji aizuchi dalam program perbincangan politik Jepun. Berbeza dengan Roslina Mamat ${ }^{13}$ yang menggunakan program televisyen Nichiyou Touron (Debat Hari Ahad), Saft menggunakan program Gekiron: Asa made Nama Terebi (Perbincangan Panas: Siaran Langsung Sehingga Pagi) sebagai data kajian. Kajian perbualan bahasa Jepun oleh penyelidik berbangsa di Jepun dan luar negara juga sangat rancak seperti Mizutani ${ }^{14}$, Saji ${ }^{15}$ (1986), Abe ${ }^{16}$, Takeuchi ${ }^{17}$, Tanaka ${ }^{18}$ dan ramai lagi. Penyelidikan wacana perbualan bahasa Jepun di Malaysia masih berada pada tahap 'selesa' dan tidak terperinci seperti mengkaji analisis kesalahan atau strategi komunikasi. Hal ini kerana Malaysia tidak mempunyai program pengajian bahasa Jepun pada peringkat pasca siswazah yang menyebabkan penyelidikan perbualan bahasa Jepun sangat terhad.

\section{Struktur luaran dalam perbualan}

Ciri luaran sesuatu bahasa tidak melihat sesuatu ayat dari segi linguistik, tidak melihat sama ada sesuatu nahu, ayat atau, frasa itu benar atau salah dari segi penggunaannya. Apa yang dilihat oleh pengkaji analisis perbualan adalah cara bagaimana seorang penutur mengujarkan sesuatu ayat seperti intonasi, jeda, celahan, kesopanan, ujaran taksa, gaya bahasa badan, bagaimana penutur mengambil giliran, ujaran akhir ujaran dan sebagainya dengan mengaitkan dapatan kajian tersebut kepada latar belakang penutur dan pendengar, masyarakat, budaya dan sifat bahasa yang digunakan. Seperti yang dinyatakan sebelum ini dalam perbualan bahasa Jepun, pengambilan giliran yang teratur dan tersusun, aizuchi dan elemen akhir ujaran sangat penting kepada peserta perbualan bagi menunjukkan kesopanan dan menjaga air muka. Dengan kata lain, ciri luaran sesuatu perbualan sangat luas dan tidak terbatas kerana segala aspek ujaran atau ayat dan latar belakang peserta perbualan perlu diambil kira dan dianalisis. Kajian sebegini menggunakan pendekatan etnografi dan ia diguna pakai oleh ahli etnografi bagi membuat kajian yang tuntas. Kebiasaannya ahli etnografi mengambil masa yang lama untuk membuat sesuatu kajian dan sekurang-kurangnya mengambil masa setahun ${ }^{19}$. Pendekatan etnografi telah lama diguna pakai oleh disiplin yang lain termasuk pengkaji bahasa.

\section{Pengambilan giliran bercakap}

Bagi melancarkan perbualan dan mengekalkan komunikasi yang harmoni, teori pengambilan giliran sangat penting untuk dipatuhi. Menurut Sacks et. al ${ }^{20}$, 'peraturan trafik' iaitu pengurusan pengambilan giliran dalam perbualan boleh membantu daripada berlakunya 'kemalangan perbualan' (perbalahan atau komunikasi tidak harmoni) dan 'trafik sesak dalam perbualan' (pertindanan dan celahan).

\footnotetext{
${ }^{11}$ Michael Haugh, "Utterance-final Conjunctive Particles and Implicature in Japanese Conversation," Pragmatics 18, no. 3, (2008): 425-451.

${ }^{12}$ Scott Saft, "Exploring Aizuchi as Resources in Japanese Social Interaction: The Case of a Political Discussion Program," Journal of Pragmatics 39, no. 7, (2007): 290-1312.

${ }^{13}$ Roslina Mamat, “Analisis Perbualan Penutur Asli Bahasa Jepun: Satu Kajian Pengambilan Giliran dan Aizuchi” (Tesis PhD, Universiti Malaya, 2004).

${ }^{14}$ Mizutani Nobuko, “Aizuchito Outou,” in Mizutani Osamu ed., Hanashi Kotobano Hyougen, (Tokyo, Chikuma Shobo, 1983), 37-44.

${ }^{15}$ Keizou Saji, “Shuujoshino Kinou," Kokugo Kokubun 26, no. 7, (1956): 23-31.

${ }^{16}$ Abe Namiko, “The Meaning of '-N Desu' in Japanese," ThoughtCo., 7 Jun 2021, https://www.thoughtco.com/what-is-ndesu-2027871.

17 Takeuchi T, Disukoosu, (Tokyo, Kuroshio, 1999).

${ }^{18}$ Hiroko Tanaka, “Turn Projection in Japanese Talk-in-Interaction," Research on Language and Social Interaction 33, no. 1, (2000): 1-38.

${ }^{19}$ Rachel Parsons, "Statistics Solutions. What is Ethnography?”, Complete Dissertation by Statistic Solutions, 15 August 2019, https://www.statisticssolutions.com/what-is-ethnography/.

${ }^{20}$ Harvey Sacks, Emanual Schegloff, and Gail Jefferson, “A Simplest Systematic for the Organization of Turn-Taking for Conversation," Language 50, no. 4, (1974): 696-735.
} 
Menurut mereka, unit yang paling asas dalam perbualan adalah pengambilan giliran kerana seseorang itu tidak bercakap sepanjang masa. Komunikasi perlu berlaku secara dua hala dan para peserta perlu mengambil giliran yang tepat mengikut budaya bahasa masing-masing. Penutur dan pendengar saling memainkan peranan masing-masing iaitu sebagai penutur perlu memberikan mesej yang sempurna dan pendengar pula memberikan maklum balas sama ada melalui jawapan, maklum balas minimal atau bahasa badan.

Menurut Roslina Mamat ${ }^{21}$, dalam bahasa Jepun, sebagaimana penutur boleh mengawal ujaran sendiri dan mengawal pengambilan giliran dalam perbualan, pendengar juga boleh mengawal perbualan atau pengambilan giliran dengan menghantar isyarat kepada penutur melalui backchanneling atau aizuchi. Oleh itu jelas menunjukkan dalam perbualan bahasa Jepun peranan penutur dan pendengar sama penting bagi memastikan perbualan berlaku secara harmoni tanpa diganggu celahan. Menurut Roslina Mamat et $\mathrm{al}^{22}$, maklum balas minimal, maklum balas dan celahan merupakan tiga elemen penting dalam perbualan bahasa Jepun. Ketiga-tiga elemen ini sebenarnya berkongsi sifat yang sama iaitu ujaran pendek yang mungkin tidak mempunyai sebarang makna semantik seperti ujaran hai, ee dan anou. Hai dan ee dalam kamus bermaksud 'ya' tetapi dari segi pragmatik bergantung pada konteks ayat, mungkin tidak mempunyai makna tetapi sangat bermakna dan penting dalam kajian analisis wacana dan pragmatik. Ujaran 'anou' pula tidak mempunyai sebarang makna kecuali diujarkan untuk mencari masa sebelum dapat mengumpul idea dan seterusnya melontarkan pandangan tersebut. ${ }^{23}$

\section{Kata akhir ujaran}

Menurut Tanaka ${ }^{24}$, elemen akhir ujaran merupakan tanda penutur semasa ingin menyerahkan hak bercakap kepada penutur seterusnya. Elemen akhir ujaran dalam bahasa Jepun seperti kopula desu, partikel akhir seperti yo dan ne, kata kerja dan komponen predikat. Tanaka juga membuat kesimpulan bahawa kombinasi elemen akhir ujaran seperti 'ndayone' merupakan tanda bahawa penutur semasa akan menamatkan ujarannya. Sebagai contoh, ayat 'Chibi Maruko-chan ga kawaiidesu' boleh diujarkan dalam berbagai cara mengikut suasana dan keperluan penutur. Ia boleh diujarkan sebagai, 'Chibi Maruko-chan ga kawaii', 'Chibi Maruko-chan ga kawaiiyo', 'Chibi Maruko-chan ga kawaiine', 'Chibi Maruko-chan ga kawaiinda', 'Chibi Maruko-chan ga kawaiindayo', 'Chibi Maruko-chan ga kawaiindane', dan 'Chibi Maruko-chan ga kawaiindayone'. Kesemua ayat bahasa Jepun ini bermaksud 'Maruko chan adalah comel'.

Walau bagaimanapun hasil kajian Roslina Mamat ${ }^{25}$ (2004) terhadap diskusi ahli parti politik Jepun, bagi mengekalkan giliran bercakap, setelah bercakap sebegitu lama, peserta perbualan membuat beberapa strategi, iaitu menukarkan bentuk masu kepada bentuk te atau shi, menggunakan desu dan $n e$ beserta intonasi tinggi, menyebut ayat dengan laju, menggunakan kata hubung ayat seperti de (dan), soshite (kemudian) dan mou hitotsu (satu lagi). Dalam hal ini, adalah amat penting bagi peserta yang merupakan pemimpin tertinggi ahli politik kerajaan dan pembangkang, menggunakan saluran media untuk memberikan hujah, sokongan dan bantahan kepada ahli politik yang lain, serta isu yang

\footnotetext{
${ }^{21}$ Roslina Mamat, “Analisis Perbualan Penutur Asli Bahasa Jepun: Satu Kajian Pengambilan Giliran dan Aizuchi” (Tesis PhD, Universiti Malaya, 2004).

${ }^{22}$ Roslina Mamat, Hazlina Abdul Halim dan Normaliza Abd Rahim, "Celahan dalam Perbualan Pemandu Pelancong Malaysia dan Pelancong Jepun," GEMA Online Journal of Language Studies 12, no. 3, (2012): 849-863.

${ }^{23}$ Roslina Mamat, “Analisis Perbualan Penutur Asli Bahasa Jepun: Satu Kajian Pengambilan Giliran dan Aizuchi” (Tesis $\mathrm{PhD}$, Universiti Malaya, 2004).

${ }^{24}$ Hiroko Tanaka, "Turn Projection in Japanese Talk-in-Interaction," Research on Language and Social Interaction 33 , no. 1, (2000): 1-38.

${ }^{25}$ Roslina Mamat, “Analisis Perbualan Penutur Asli Bahasa Jepun: Satu Kajian Pengambilan Giliran dan Aizuchi” (Tesis PhD, Universiti Malaya, 2004).
} 
dibicarakan. Oleh itu secara bijak, peserta perbualan memanipulasi kata akhir ujaran supaya hujah mereka didengari dan difahami oleh peserta lain.

\section{Kesopanan Bahasa Jepun}

Kesopanan bahasa Jepun boleh dibahagikan kepada empat kategori iaitu Sonkeigo (bahasa hormat), Teineigo (bahasa sopan), Kenjougo (bahasa merendah diri) dan Bikago (pertuturan indah atau elegan). Sonkeigo adalah aras kesopanan tertinggi diikuti Teneigo, Kenjougo dan Bikago. Sonkeigo adalah bentuk unik yang digunakan dalam komunikasi antara orang atasan dan bawahan atau pembekal perkhidmatan dan penerima perkhidmatan seperti doktor dan pesakit. Sebagai contoh, bentuk ayat sopan "suwatte kudasai" (sila duduk) akan digantikan dengan bahasa hormat "okakeni natte kudasai" atau "osuwari kudasai", yang membawa maksud yang sama.

Teneigo pula adalah kata kerja bentuk masu atau kopula desu yang mula-mula dipelajari oleh majoriti pelajar bahasa Jepun dalam buku teks. Kata kerja dalam bahasa Jepun berada pada akhir ayat, dan bentuk masu kata kerja ini digunakan bagi menunjukkan kesopanan dalam perbualan. Kata kerja bentuk masu dan kopula desu merupakan bentuk kesopanan yang paling asas dalam bahasa Jepun. Contoh Teineigo adalah watashi wa ashita ikimasu (saya akan pergi esok) atau jussai desu (berumur sepuluh tahun). Kata kerja masu atau kopula desu bertukar kepada mashita atau deshita bagi kala lampau. Bentuk negatif bagi masu dan desu pula adalah masen dan ja arimasen atau dewa arimasen dan akan bertukar kepada masen deshita dan ja arimasen deshita atau dewa arimasen deshita bagi negatif kala lampau.

Kenjougo bermaksud bahasa merendah diri ketika merujuk kepada diri sendiri atau pihak diri sendiri seperti 'keluarga saya' atau 'syarikat saya'. Dalam perbualan perniagaan Kenjougo biasa digunakan bagi merendahkan diri sendiri dan menaikkan pihak yang dilawan bercakap. Contoh ayat Kenjougo adalah 'onaka ga suite mairimashita' (saya sudah lapar) bagi menggantikan ayat 'onaka ga sukimashita' (teineigo) atau 'onaka suita' (bahasa kasual).

Bikago atau Bahasa Indah pula merujuk kepada pemilihan kata yang lebih khusus bagi mengindahkan lagi perkataan atau pertuturan tersebut. Ia biasa digunakan dalam tanka (sajak Jepun). Bikago digunakan oleh penutur menambahkan pemurniaan kepada gaya pertuturan seseorang. Contoh bikago adalah oniwa (taman), onomimono (minuman), oshokuji (makan) dan oryouri (masakan) bagi menggantikan niwa, nomimono, shokuji dan ryouri iaitu dengan menambahkan o di hadapan kata. Penutur juga boleh meletakkan ' go' kepada kata seperti gokyoudai (adik beradik) bagi kyoudai. Tetapi bukan semua kata boleh diletakkan $o$ atau go di hadapan. Penggunaan yang kerap dan pada perkataan yang tidak sesuai boleh menjadikan ayat yang diujarkan tidak sesuai dengan konteks dan boleh disalah faham. Kesopanan bahasa Jepun boleh diringkaskan kepada Jadual 1 berikut. 
Jadual 1: Kesantunan Bahasa Jepun ${ }^{26}$

\begin{tabular}{|c|c|c|c|}
\hline & Kategori & Kompenan & Kompenan \\
\hline \multirow{4}{*}{ Keigo } & \multirow{2}{*}{$\begin{array}{c}\text { Sozai keego } \\
\text { (subjek/penerima honorifik) }\end{array}$} & $\begin{array}{l}\text { Sonkeego } \\
\text { (Honorific language) }\end{array}$ & Sonkeego \\
\hline & & $\begin{array}{l}\text { Kenjoogo } \\
\text { (humble language) }\end{array}$ & \multirow[b]{2}{*}{ Kenjoogo } \\
\hline & \multirow{2}{*}{$\begin{array}{c}\text { Taisha keego } \\
\text { (objek/perujuk honorifik) }\end{array}$} & $\begin{array}{l}\text { Teechoogo } \\
\text { (courteous language) }\end{array}$ & \\
\hline & & $\begin{array}{l}\text { Teeneego } \\
\text { (polite language) }\end{array}$ & \multirow[b]{2}{*}{ Teeneego } \\
\hline \multicolumn{2}{|c|}{ Neutral/standard honorific } & $\begin{array}{l}\text { Bikago } \\
\text { (elegant speech) }\end{array}$ & \\
\hline
\end{tabular}

Seperti juga bahasa lain di dunia, bahasa Jepun juga mempunyai bahasa kasual yang dikenali juga Futsuu Tai bagi pelajar bahasa Jepun. Bahasa kasual adalah bahasa pertuturan yang digunakan dalam kalangan rakan rapat, keluarga dan golongan yang berada dalam tahap sosial yang sama. Contohnya Arisan wa isha da (Encik Ali adalah doktor) bagi ayat Arisan wa isha desu (Teineigo) atau watashi wa kesa tabenakatta (saya pagi tadi tidak makan) bagi menggantikan watashi wa kesa tabemasen deshita (Teineigo). Dalam bahasa kasual untuk dua ayat ini kopula desu digantikan dengan da dan kata kerja tabenakatta menggantikan tabemasen deshita. Jadual 2 berikut menunjukkan kopula dan kata kerja dalam bentuk kesopanan (atau Teineigo) dan bentuk kasual.

Jadual 2:Kopula dan Kata Kerja dalam Bentuk bahasa Kesopanan (Teineigo) dan Bahasa Kasual (Futsuu Tai) ${ }^{27}$

\begin{tabular}{|c|c|c|c|c|c|}
\hline $\begin{array}{c}\text { Kopula/ } \\
\text { kata kerja }\end{array}$ & $\begin{array}{l}\text { Bentuk } \\
\text { Bahasa }\end{array}$ & $\begin{array}{c}\text { Kala kini/ kala } \\
\text { hadapan }\end{array}$ & Kala lampau & $\begin{array}{c}\text { Negatif } \\
\text { Kala kini/kala } \\
\text { hadapan }\end{array}$ & $\begin{array}{c}\text { Negatif } \\
\text { kala lampau }\end{array}$ \\
\hline \multirow[t]{2}{*}{ Kopula } & Teineigo & desu & deshita & dewa (ja) arimasen & $\begin{array}{c}\text { dewa (ja) arimasen } \\
\text { deshita }\end{array}$ \\
\hline & Futsuи Tai & $d a$ & Datta & dewa (ja) nai & dewa (ja) nakatta \\
\hline \multirow{7}{*}{$\begin{array}{l}\text { Kata } \\
\text { kerja }\end{array}$} & \multirow{3}{*}{ Teineigo } & -masu & -mashita & -masen & -masen deshita \\
\hline & & ikimasu & ikimashita & ikimasen & ikimasen deshita \\
\hline & & tabemasu & tabemashita & tabemasaen & tabemasen deshita \\
\hline & \multirow{4}{*}{ Futsuu Tai } & $i k u$ & Itta & ikanai & ika nakatta \\
\hline & & taberu & tabeta & tabenai & tabe nakatta \\
\hline & & kuru & Kita & konai & ko nakatta \\
\hline & & dasu & dashita & dasanai & dasa nakatta \\
\hline
\end{tabular}

\section{Celahan.}

Penyelidik dalam bidang wacana pada umumnya berpendapat bahawa bukan semua celahan bertujuan untuk mengganggu penutur semasa kerana terdapat celahan yang bertujuan untuk membantu atau

\footnotetext{
${ }^{26}$ Iori Isao, Takanashi Shino, Nakanishi Kumiko, and Yamada Toshihiro, "Shokyuu o oshieru hito no tameno Nihongo bunpoo handobukku", (Tokyo, 3A Corporation, 2000).

${ }^{27}$ Sumber: daripada penulis yang telah mengajar Bahasa Jepun lebih daripada 25 tahun.
} 
menyokong penutur semasa. Roslina Mamat, Hazlina Abdul Halim dan Normaliza Abd Rahim ${ }^{28}$ pernah membuat kajian mengenai celahan dalam perbualan pemandu pelancong Malaysia dan pelancong Jepun. Dapatan kajiannya secara jelas menunjukkan penutur asli bahasa Jepun merasa terganggu dengan celahan pemandu pelancong berdasarkan intonasi penutur selepas gilirannya dirampas oleh pemandu pelancong Malaysia. Hal ini boleh difahami kerana masyarakat Jepun menunggu sehingga kepada akhir ujaran penutur semasa sebelum mengambil giliran. Selagi penutur semasa tidak memberi tanda awal bahawa dia akan berhenti bercakap, selagi itulah pendengar memberi maklum balas minimal supaya penutur dapat meneruskan ujaran.

\section{Penggunaan partikel ne selepas sesuatu unit idea.}

Partikel ne mempunyai berbagai-bagai fungsi walaupun tidak mempunyai makna yang khusus. Ia boleh digunakan pada akhir ayat atau akhir frasa dan klausa serta boleh juga digunakan pada akhir setiap unit idea. Ia boleh berfungsi untuk menunjukkan bahawa penutur bersetuju dengan pendengar, memberitahu maklumat yang sama-sama diketahui oleh penutur dan pendengar, menunjukkan perasaan simpati atau sekadar menarik perhatian atau mendapatkan kepastian pendengar jika ia diujarkan dalam intonasi yang tinggi.

\section{METODOLOGI}

\section{Reka Bentuk Kajian}

Kajian ini menggunakan pendekatan kualitatif yang mengaplikasikan pemerhatian sistematik terhadap interaksi di sepanjang sesi lawatan pelancongan. Pendekatan ini memfokuskan pengkajian terhadap sesuatu fenomena atau situasi dalam konteks sebenar atau semula jadi. Melalui pendekatan ini kefahaman yang mendalam tentang ciri-ciri luaran bahasa dan hubungannya dengan budaya dalam konteks perbualan antara pemandu pelancong dan pelancong dapat dikenal pasti.

\section{Data Kajian}

Data kajian diperolehi daripada empat sesi perbualan dalam pelancongan berbentuk Free Independent Travel (FIT) telah dilakukan di Melaka dan Tokyo. Dua sesi perbualan menggunakan bahasa Jepun oleh pemandu pelancong Malaysia bersama pelancong Jepun dan dua lagi sesi perbualan menggunakan bahasa Jepun oleh pemandu pelancong Jepun bersama pelancong Malaysia. Rakaman video, audio, visual, pemerhatian dan catatan dilakukan bagi mendapatkan data-data ini. Rakaman turut disertai penyelidik kajian yang merekod perbualan dan membuat catatan.

\section{Lokasi Kajian}

Sesi lawatan pakej FIT ini dikendalikan di sekitar destinasi pelancongan bandar raya Melaka di Malaysia, bandaraya Tokyo dan Yokohama di Jepun. Lokasi ini dipilih kerana ia merupakan destinasi pelancongan utama dan yang tidak pernah dikunjungi oleh para pelancong yang terlibat dalam kajian ini.

\footnotetext{
${ }^{28}$ Roslina Mamat, Hazlina Abdul Halim dan Normaliza Abd Rahim, "Celahan dalam Perbualan Pemandu Pelancong Malaysia dan Pelancong Jepun,” GEMA Online Journal of Language Studies 12, no. 3, (2012): 849-863.
} 


\section{Responden Kajian}

Dua kategori responden terlibat dalam kajian ini iaitu pemandu pelancong dan pelancong. Mereka terdiri daripada dua orang pemandu pelancong Malaysia berbahasa Jepun dan dua orang pemandu pelancong natif bahasa Jepun. Manakala responden dari kategori pelancong pula ialah dua orang pelancong Jepun dan dua orang pelancong Malaysia terlibat dalam kajian ini. Kedua-dua kategori responden kajian ini dirujuk sebagaimana Jadual 3.

\section{Jadual 3: Rujukan Responden Kajian}

$\begin{array}{lll}\text { JTG1 \& } 2 & : & \text { Japanese Tourist Guide } 1 \& 2 \\ \text { MTG1 \& } 2 & : & \text { Malaysian Tourist Guide } 1 \& 2 \\ \text { MT1 \& 2 } & : & \text { Malaysian Tourist } 1 \& 2 \\ \text { JT1 \& } 2 & : & \text { Japanese tourist } 1 \& 2\end{array}$

\section{Penganalisisan Data}

Rakaman ditranskripsi secara verbatim untuk melihat ciri-ciri luaran bahasa dan kesopanan yang diujarkan. Transkripsi perbualan ini dianalisis dengan mengekod dan mengkategorikan kesopanan berdasarkan Kesantunan Bahasa Jepun oleh Iori et. al ${ }^{29}$. Rakaman transkripsi ditandai dengan bacaan sebagaimana Jadual 4. Hanya perbualan oleh pemandu pelancong yang dianalisis dan dimuat dalam kandungan artikel ini kerana fokus kajian lebih kepada bentuk luaran dan kesopanan bahasa Jepun yang digunakan oleh pemandu pelancong Malaysia dan Jepun dalam menunjukkan solidariti dan persamaan dalam konteks perbualan silang budaya.

\section{Jadual 4: Tanda Bacaan Transkripsi Rakaman}

$\begin{array}{lll}(\quad) & : & \text { Aizuchi } \\ \text { xxx } & : & \text { ujaran yang tidak dapat dikenal pasti } \\ \text { //I } & : & \text { Jeda }\end{array}$

Terdapat juga kata yang tidak dapat diterjemahkan seperti 'anou' yang tidak mempunyai sebarang makna tetapi diujarkan hanya sebagai isyarat untuk memulakan ayat atau mengambil giliran bercakap. Ia juga digunakan sebagai satu strategi untuk melengahkan masa jika penutur semasa sedang mencari unit idea tertentu dalam perbualan. Oleh itu ujaran 'anou', 'eeto', 'maa' dan sebagainya tidak diterjemahkan dan dikekalkan dalam bahasa Jepun. Ujaran sebegini dikenali sebagai fillers atau bahasa Melayunya 'pengisi', seperti ujaran ' $h m m$ ' yang tidak membawa sebarang makna semantik tetapi mempunyai makna pragmatik sebagai pengisi, iaitu mengisi uajran semasa sambil mencari unit idea yang tertentu.

\footnotetext{
${ }^{29}$ Iori Isao, Takanashi Shino, Nakanishi Kumiko, and Yamada Toshihiro, "Shokyuu o oshieru hito no tameno Nihongo bunpoo handobukku", (Tokyo, 3A Corporation, 2000).
} 


\section{DAPATAN DAN PERBINCANGAN}

Dapatan kajian menunjukkan lima fitur kesopanan iaitu empat elemen akhir ujaran dan satu elemen kesopanan pada kata nama. Empat elemen akhir ujaran tersebut adalah kata kerja bentuk -masu atau desu, -ne, -ndesu dan -nandesu. Sebagai contoh bentuk -masu adalah tabemasu (makan), elemen akhir -ne adalah tabemasune atau taberune, -ndesu adalah taberundesu atau tabetandesu dan eleman kesopanan pada kata nama adalah sashimi nandesu (adalah sashimi). Satu lagi elemen adalah elemen penambahan $o$ dan go sebelum kata nama seperti okane (wang) dan obentou (bekal). Jadual 5 menunjukkan jumlah penggunaan kata kerja yang menunjukkan kesopanan iaitu bentuk masu, penggunaan pertuturan elegan iaitu menambahkan karakter 'o' atau 'go' pada awal kata bagi menunjukkan kesopanan, penggunaan $-n$ desu bagi meneutralkan kembali kata kerja yang bersifat kasual dan penggunaan nan desu bagi meneutralkan kembali kata nama yang bersifat kasual. Nan bermaksud 'apa' tapi dalam ayat yang dibincangkan ini, nan tidak membawa makna kecuali bagi menguatkan ayat. Jadual 5 juga menunjukkan bagaimana pemandu pelancong Malaysia memonopoli penggunaan pertuturan yang elegan dan partikel ne di akhir ayat.

Penggunaan partikel ne pada akhir ayat atau frasa oleh kedua-dua pemandu pelancong Malaysia dan Jepun, membuktikan bagaimana ne begitu sinonim dalam perbualan bahasa Jepun. Ujaran akhir ne menunjukkan bagaimana keempat-empat responden berkongsi perasaan atau maklumat yang sama. Responden telah mengandaikan bahawa peserta perbualan iaitu pelancong Malaysia di Jepun dan pelancong Jepun di Malaysia telah mengetahui maklumat yang ingin disampaikan. Ini kerana partikel ne, selain menunjukkan simpati pada pendengar turut membawa maksud bahawa maklumat yang sedang disampaikan adalah maklumat sudah sedia maklum bersama. Di sini pemandu pelancong cuba menunjukkan bahawa pelancong yang berlainan bangsa dan bahasa dengan mereka tidak kekurangan maklumat tentang negara yang dilawati seterusnya mengangkat pengetahuan pelancong kepada tahap yang tinggi pada negara yang dilawati. Ini berlawanan sekiranya pemandu pelancong menggunakan partikel yo pada akhir ujaran, yang menunjukkan maklumat yang diberitahu adalah maklumat baharu yang pelancong tidak mempunyai pengetahuan.

Jadual 5: Fitur perbualan pemandu pelancong Jepun dan Malaysia ${ }^{30}$

\begin{tabular}{|l|c|c|c|c|}
\hline $\begin{array}{c}\text { Elemen } \\
\text { kesopanan }\end{array}$ & JTG1 & JTG2 & MTG1 & MTG2 \\
\hline masu Form & 134 & 51 & 92 & 100 \\
\hline $\begin{array}{l}\text { Pertuturan elegano } \\
\text { bersama kata nama }\end{array}$ & 0 & 1 & 28 & 120 \\
\hline -ne & 344 & 73 & 1022 & 553 \\
\hline -n desu & 4 & 3 & 45 & 28 \\
\hline -nan desu & 13 & 4 & 26 & 105 \\
\hline Jumlah & 495 & 136 & 1213 & 906 \\
\hline
\end{tabular}

\section{Penggunaan kata kerja bentuk masu}

Pada Data Perbualan 1 berikut, pemandu pelancong terlebih dahulu membuka perbualan dengan ucapan selamat pagi ohayo gozaimasu dan dibalas MT2, selanjutnya MT1 mengujarkan yoroshiku onegaishimasu kepada JTG1.

\footnotetext{
${ }^{30}$ Iori Isao, Takanashi Shino, Nakanishi Kumiko, and Yamada Toshihiro, "Shokyuu o oshieru hito no tameno Nihongo bunpoo handobukku”, (Tokyo, 3A Corporation, 2000)
} 


\section{Data Perbualan 1}

\section{JTG1: Ohayou gozaimasu.}

[Selamat pagi]

MT2: Ohayou gozaimasu

MT1: Yoroshiku onegaishimasu.

[Sila beri tunjuk ajar]

JTG1: Yoroshiku onegaishimasu.

[Sila beri tunjuk ajar]

\section{Penggunaan penambahan kopula desu pada ayat kata kerja}

Pada Data Perbualan 2 pula JTG2 menggunakan kopula desu pada akhir ayat. Seperti masu, desu juga merupakan bentuk kesopanan yang paling asas. JTG2 mengujarkan 'nihonjin janaito ikenai desu'. JTG2 boleh mengujarkan "nihonjin janai to ikemasen" yang merupakan bentuk masu, tetapi sebaliknya menggunakan 'nihonjin janai to ikenai...". 'Ikenai' merupakan bentuk kurang sopan dan berbentuk kasual yang hanya dituturkan dalam perbualan antara rakan yang mesra. Oleh itu JTG2 menambah desu selepas ikenai bagi menunjukkan kesopanan.

\section{Data perbualan 2}

JTG2: Nihonjin janai to ikenai desu. Inai to omoimasu ne.

Mareeshiago no gaido. Mareegono gaidosan inai desu.

[Tidak boleh kalau bukan orang Jepun. Saya rasa tiada. Pemandu pelancong berbahasa Malaysia. Tiada pemandu pelancong berbahasa Melayu]

MT1: Tabun mareeshiajin eigo tsuujirukara ne.

[mungkin kerana orang Malaysia faham bahasa Inggeris]

JTG2: Sou desu ne. Eigo de sundan desu ne.

[ya, betul. Dengan bahasa Inggeris, selesai]

Perkara yang sama berlaku dalam ayat "Mareego no gaidosan inai desu" dan "Eigo de sundan desu ne". Desu ditambahkan kepada kata kerja bentuk kasual yang tidak sopan 'inai' dan 'sunda' bagi mengembalikan kesopanan kepada ayat. Penggunaan kata kerja bentuk masu atau desu pada akhir ayat banyak digunakan dalam perbualan sama ada dalam perbualan oleh pemandu pelancong Malaysia mahupun Jepun. Ia merupakan sistem kesopanan bahasa Jepun yang paling asas. 


\section{Penggunaan -ndesu pada akhir ujaran}

Pada Data Perbualan 3 berikut, JTG1 mengujarkan 'itan desu ka' (telah tinggal di mana?) iaitu menambahkan ' $n$ desu' kepada kata kerja bentuk kasual.

\section{Data Perbualan 3}

JTG1: Nihon ni doko ni itan desu ka?

[tinggal di mana di Jepun]

MT1: Hiroshima.

JTG1 menggunakan bentuk kasual lalu ditambahkan ' $n$ desu' supaya ayat menjadi lebih sopan. Berikut adalah tahap kesopanan bagi ayat yang mempunyai makna yang sama iaitu 'tinggal di mana semasa di Jepun'. Ketiga-tiga ayat ini mempunyai kata yang sama, kecuali ujaran akhir ayat yang sedikit berbeza. Partikel $k a$ di akhir ujaran menunjukkan kata tanya.

\section{Nihon ni doko ni imashita ka? [Bentuk masu yang sopan]}

2. Nihon ni doko ni ita ka? [Bentuk kasual yang tidak sopan]

3. Nihon ni doko ni itan desu ka? [bentuk kasual ditambahkan $n$ desu supaya lebih sopan]

JTG 1 menggunakan jenis ayat ketiga, iaitu ayat kedua yang ditambah $-n$ desu, bagi meneutralkan kembali ayat yang berbentuk kasual.

Pada Data Perbualan 4 pula, JTG1 menambahkan 'nan' kepada kata nama 'nezumi' (tikus). Responden boleh sahaja mengujarkan 'nezumi desu' tetapi memilih untuk mengujarkan 'nezumi nan desu' bagi melembutkan ayat. Kata kerja bentuk kasual atau lebih dikenali sebagai 'Futsuu Tai' dalam bahasa Jepun, seperti juga bahasa yang lain digunakan ketika berkomunikasi dengan rakan perbualan yang mesra, kalangan keluarga, kawan atau rakan sekerja yang mempunyai status yang sama. Jika bercakap dengan orang yang tidak rapat, lebih berumur atau mempunyai kelas sosial yang lebih tinggi, penutur akan bercakap menggunakan sekurang-kurangnya bentuk masu. Makna semantik 'nan' adalah 'apa' tetapi dalam konteks '-nan desu', 'nan' dalam 'nezumi nan desu' tidak mempunyai sebarang makna kecuali salah satu bentuk kolokial atau penegasan penutur semasa terhadap sesuatu perkara yang mungkin tidak diketahui oleh pendengar.

\section{Data Perbualan 4}

JTG1: Rainen ga nezumi nan desu. Ironna onegai ga arimasu.

[tahun depan tahun tikus. Ada berbagai-bagai permintaan]

\section{MT2: Kore wa arabiago no kamoyo.}

[Ini dalam bahasa Arab, itik]

Data Perbualan 5 berikut pula, menunjukkan MTG1 menggunakan bentuk $-n$ desu. MTG1 boleh sahaja menggunakan kata kerja bentuk masu bagi dekiru iaitu dekimasu, menjadi densha mo dekimasu (keretapi pun boleh), sebaliknya dia menukar kepada kata kerja kepada bentuk kasual dan menambahkan $n$ desu bagi meneutralkan kembali ayat. 


\title{
Data Perbualan 5
}

\author{
JT1: yappari shingapooru kara kuara runpuuru made kaerou to \\ omottara (MTG1: hai) anou, maa hikouki ka basu ka densha mo \\ totterun desu ka?
}

[sebenarnya dari Singapura ke Kuala Lumpur, kalau mahu balik (ya) anou, maa kapal terbang atau bas atau keretapi pun bolehkah?]

MTG1: a, densha mo omoshiroi desu. Densha mo dekirun desu...

[ya, dengan kereta api pun seronok. Kereta api pun boleh...]

Bentuk - $n$ desu juga kerap digunakan dalam perbualan bahasa Jepun. Ini kerana dalam perbualan biasa dalam kalangan keluarga, rakan dan ahli sesuatu organisasi, bentuk kasual sering digunakan kerana ia mudah dan sesuai berbanding bentuk kesopanan bahasa Jepun. Hanya dengan menambahkan - $n$ desu pada akhir ayat bentuk kasual, seluruh ayat telah mencapai standard minimum dalam kesopanan berbahasa. Sebenarnya dalam bahasa Jepun bentuk kesopanan sangat sukar untuk digunakan dalam perbualan walaupun dalam kalangan rakyat Jepun kecuali mereka yang berada dalam bidang perkhidmatan. Dalam perbualan biasa atau perbualan harian, mereka tidak perlu pun menggunakan bentuk ini. Mereka menggunakan bentuk ini sekiranya mereka terlibat dalam pekerjaan yang melibatkan industri perkhidmatan atau setelah mereka memasuki sesuatu syarikat atau organisasi. Mereka akan dilatih atau terbiasa menggunakan bentuk-bentuk bahasa sopan ini setelah berada dalam tempoh tertentu. Oleh itu, tidaklah pelik sekiranya penutur kedua atau ketiga bahasa Jepun termasuk penulis sendiri jarang menggunakan bentuk sebegini dan ditambah lagi dengan kosa kata bahasa sopan yang terhad dalam pemerolehan penutur kedua dan ketiga berbanding penutur natif bahasa Jepun.

\section{Penggunaan partikel ne selepas sesuatu unit idea}

Pada Data Perbualan 6 berikut, JTG1 mengujarkan empat partikel ' $n e$ ' dalam satu pengambilan giliran. Partikel ne yang pertama dan kedua, 'koko wane toukyou eki ne' (sini stesen Tokyo) digunakan untuk menarik perhatian pendengar kepada topik cerita iaitu 'sini' atau lebih spesifik 'Tokyo'. Partikel ne yang ketiga 'nagasa ga 335 meetaa ne' (panjang 335 meter) digunakan untuk memberitahu maklumat yang dianggap pendengar sudah ketahui dan partikel ne yang keempat 'kochira ne' (sini) diujarkan untuk menarik perhatian pendengar kepada topik perbualan iaitu 'kochira' atau 'sini'.

\section{Data Perbualan 6}

JTG1: koko wane toukyou eki ne. (hai) nagasa ga 335 meetaa ne. Toukyou tawa ga 333 meeta (hai) 333. 333 dakara, kochira ne nagasa wa toukyou yori nagai desu. (hai) koko ga kitagawa, koko chuoguchi, mukou ga minami guchi, (hai) kita kara minamini domu ga aru.

[sini stesen Tokyo. (ya) panjang 335 meter. Tokto Tower 333 meter (ya). Sebab 333 lebih panjang dari Tokyo. (ya) sini sebelah utara, sini central exit, sebelah sana south exit, (hai) dari utara sehingga selatan ada Dome.] 
MT1: doku?

[penutur memastikan perkataan yang didengar]

TG1: doоти,doоти.

[dome, dome]

Data perbualan 7 juga menunjukkan responden menggunakan dua kali partikel $n e$ dalam satu ayat. Ini menunjukkan bagaimana penggunaan $n e$ begitu sinonim dan kerap digunakan dalam perbualan bahasa Jepun. Hal ini kerana penutur ingin menarik perhatian pendengar kepada sesuatu unit idea yang ingin disampaikan.

\section{Data Perbualan 7}

T1: $\quad$ nanka watashi no tomodachi demo anou, isuramu no kata to kekkonshite, nihonjin, nannin ka iru desu ne, kiitara, ya, ichiban, hitori dake nanka dannasan ni shuunyuu nai kara, uchiwa muri to omotte.

[Kawan saya ada yang berkahwin dengan orang Islam. Terdapat beberapa orang (yang berkahwin dengan orang Jepun). Apabila yang paling hanya seorang yang mengatakan suami tiada pendapatan. Saya mungkin tidak boleh (berbuat demikian)]

MTG1: $\quad$ sore wane, joudan dake (hai) abunai dakara ne, my first wife will kill me...

[itu, Cuma bergurau (ya) kerana bahaya, my first wife will kill me...]

\section{Penggunaan Pertuturan Elegan}

Pada Data Perbualan 6 berikut, JTG1 mengujarkan empat partikel ' $n e$ ' dalam satu pengambilan giliran. Partikel ne yang pertama dan kedua, 'koko wane toukyou eki ne' (sini stesen Tokyo) digunakan untuk menarik perhatian pendengar kepada topik cerita iaitu 'sini' atau lebih spesifik 'Tokyo'. Partikel ne yang ketiga 'nagasa ga 335 meetaa ne' (panjang 335 meter) digunakan untuk memberitahu maklumat yang dianggap pendengar sudah ketahui dan partikel ne yang keempat 'kochira ne' (sini) diujarkan untuk menarik perhatian pendengar kepada topik perbualan iaitu 'kochira' atau 'sini'.

Data perbualan 8 menunjukkan JTG2 menggunakan bentuk sopan ohiru bagi menggantikan hiru (makan tengahari) dan okane bagi menggantikan 'kane' (wang). Hiru bermaksud 'tengahari' tetapi dalam konteks perbualan ini, ia merujuk kepada 'hiru gohan', iaitu 'makan tengahari'. Sebenarnya penambahan 'o' dan 'go' bagi sesetengah kata nama menunjukkan rasa hormat penutur kepada pendengar. Kata nama seperti sake (arak), kane dan hiru (tengahari) ditambahkan ' $o$ ' di depan bagi menunjukkan kesopanan, tetapi kini osake, okane dan ohiru telah menjadi perkataan umum dan tidak lagi merujuk kepada sistem kesopanan dalam perbualan bahasa Jepun, sehingga jika mengujarkan kane dan hiru tanpa menambah o, perkataan itu menjadi sedikit janggal dan kasar. 


\section{Data Perbualan 8}

JTG2: Anou ohiru ga ryokougaisha ga xxx yatteru kara (hai) hokano no mono o erande watashi wa okane o (hai) haratte mo iidesu keredemo...

[Untuk makan tengahari akan xxx oleh syarikat pelancongan (ya).

Pilih yang lain saya akan bayar (ya) pun boleh...

MT1: Wakarimashita.

[Baik]

Data Perbualan 9 pula, responden menggunakan perkataan 'okyaku sama' (kata panggilan sopan untuk pelanggan) bagi menggantikan kata nama 'okyakusan'. Seperti yang dinyatakan dalam perbualan 8, 'okyaku san', walau 'o' ditambah pada bahagian hadapan tidak cukup untuk menunjukkan kesopanan kerana 'okyakusan' telah begitu meluas digunakan sehingga tidak mencerminkan unsur kesopanan. Oleh itu selain menambah 'o', responden menggantikan panggilan 'san' kepada 'sama' yang mana ia lebih menonjolkan kesopanan apabila berkomunikasi dengan pelanggan. 'San' merupakan kata panggilan kepada seseorang yang ditambah kepada nama seseorang seperti 'Tanaka san' yang bermaksud 'Cik, Puan, Encik, Tuan Tanaka', manakala, 'sama' pula diletakkan selepas nama seseorang yang jauh lebih tinggi kedudukan seperti golongan raja atau bangsawan. Karakter 'sama' dalam kanji juga merupakan sebahagian daripada kata nama 'kamisama' iaitu 'Tuhan'.

\section{Data Perbualan 9}

MT1: Yoroshiku onegaishimasu.

[sila beri tunjuk ajar]

JTG1: Yoroshiku onegaishimasu.//I a, ima, uun okyakusama doko shitsurei desu keredemo, (Hai) maa, doko ni sunde imasu ka?

[Sila beri tunjuk ajar./// a, sekarang. Uun, anda mana mungkin tidak sopan untuk bertanya tetapi tinggal di mana?

Data Perbualan 10 berikut menunjukkan bagaimana MTG2 menggunakan obentou bagi kata nama bentou (lunch box). Penggunaan 'o' pada hadapan bentou jelas menunjukkan bahawa MTG2 cuba menggunakan bentuk sopan bagi kepada keseluruhan ayat. Ini kerana salah satu bentuk kesopanan dalam satu ayat yang panjang sudah memadai bagi menonjolkan sisi rendah hati penutur, sebagai pemandu pelancong dan juga penutur bukan natif bahasa Jepun.

\section{Data Perbualan 10}

MTG2: $\quad$ sou, isetanni itte ne, kaku bashoni yotte, anou rottoten no isetan no suupaa no naka ni ne, hachiji ni nattara, obentou zenbu hangaku ne (soudesu ka) yoku asoko de somen o kaimasu...

[ya, pergi ke isetan, bergantung pada tempat, anou, dalam mall isetan di lot 10, bila pukul lapan, semua lunch box separh harga (yake) saya selalu beli somen di situ...] 
JT2: aa, sorewa iidesune.

[aa, bagus tu]

Pertuturan elegan digunakan dalam perbualan bukan sahaja bagi menunjukkan kesopanan tetapi juga untuk mencantikkan ayat dan menonjolkan sisi penutur yang elegan. Dengan pemilihan kata tertentu, pendengar akan mempunyai tanggapan yang positif terhadap penutur selain merasakan dirinya dihargai. Ini akan menyebabkan perbualan berlaku lebih harmoni dengan masing-masing cuba menggunakan sebanyak mungkin kesopanan dalam perbualan.

Hasil daripada pencirian data secara keseluruhan dapat disimpulkan bahawa tiada perbezaan nyata dalam penggunaan struktur luaran perbualan bahasa Jepun oleh pemandu pelancong Malaysia dan Jepun. Malah terdapat banyak persamaan dalam pemilihan kosa kata dan bentuk kata kerja tertentu oleh pemandu pelancong Jepun dan Malaysia bagi menunjukkan kesopanan dan kemesraan dalam perbualan. Secara tidak langsung kajian ini menunjukkan kemahiran bahasa Jepun oleh MTG sebagai medium semasa mengendalikan lawatan pelancongan adalah setanding dengan JTG.

\section{KESIMPULAN}

Kajian ini telah mencapai objektif yang digariskan dan dapatan kajian ini memberi sorotan tambahan kepada kajian lampau dengan penerokaan perincian struktur luaran perbualan bahasa Jepun oleh para TG semasa mengendalikan lawatan pelancongan. Walaupun kajian mendapati struktur luaran bahasa Jepun yang digunakan oleh MTG adalah setanding dengan JTG namun penekanan penguasaan aspek ini tetap perlu diperkukuh. Para MTG bukan hanya perlu menguasai bahasa Jepun dengan mahir malah perlu mengenal pasti sifat bahasa dan unsur budaya yang mendasari tatacara berbahasa sesebuah peristiwa komunikasi. Ini kerana tatacara berbahasa seseorang dipengaruhi oleh norma budaya masyarakatnya yang sudah mendarah daging pada diri yang akan membentuk pola pertuturan seseorang. Tatacara berbahasa ini sangat penting demi kelancaran sesebuah komunikasi. Data menunjukkan pemandu pelancong Malaysia menggunakan fitur kesopanan hampir dua kali ganda lebih tinggi berbanding pemandu pelancong Jepun. Hal ini berlaku kerana pemandu pelancong Malaysia telah memahami sepenuhnya budaya dan bahasa Jepun yang sesuai ketika berinteraksi dalam bidang perkhidmatan. Orang Jepun juga merasa tidak selesa apabila penutur bukan natif tidak mengendahkan 'taraf sosial' apabila berkomunikasi dengan penutur natif ${ }^{31}$. Secara langsung atau secara tidak lansung penutur natif dipercayai lebih tinggi 'taraf' berbanding penutur bukan natif jika kedua-dua mereka menggunakan bahasa Jepun. Perkara sebegini tidak berlaku jika kedua-dua pihak menggunakan bahasa Inggeris yang tidak mempunyai sistem kesopanan yang kompleks berbanding bahasa Jepun.

Penyelidikan ini diharapkan akan menjadi rujukan kepada tenaga pengajar bahasa Jepun dalam mencari pendekatan atau teknik yang bertepatan dalam merencanakan rancangan pembelajaran, khususnya pembelajaran bahasa Jepun untuk pelancongan. Pada masa hadapan diharap terdapat pengkaji bahasa Jepun lain yang boleh meneliti pola pertuturan pemandu pelancong tempatan dalam bilangan yang lebih besar supaya dapatan kajian lebih tepat. Hal ini kerana walaupun pada dasarnya jumlah empat sesi perbualan pelancongan dalam kajian ini telah mencapai tahap yang mencukupi bagi kajian kualitatif, namun mungkin masih terdapat faktor lain yang menjadi penentu kepada pola pertuturan jika lebih banyak responden digunakan. Kajian ini menyumbang kepada kesedaran dan keperluan untuk memasukkan kecekapan komunikatif antara budaya ke dalam program pelancongan yang dapat menghasilkan graduan yang lengkap dan bersedia untuk persekitaran kerja multibahasa dan multibudaya.

\footnotetext{
${ }^{31}$ Berdasarkan pengalaman penulis ketika berinteraksi dengan penutur asli bahasa Jepun yang lebih berumur dan ketika mengajar pelajar universiti Jepun selama dua tahun.
} 


\section{PENGHARGAAN DAN PENGISYTIHARAN}

Para penulis merakamkan penghargaan kepada para penilai tanpa nama (anonymous reviewers) kerana kesudian penilaian serta cadangan penambahbaikan kualiti manuskrip. Tiada potensi konflik berkepentingan sepanjang proses penerbitan. Penghasilan artikel ini juga tidak dibiayai oleh sebarang geran penyelidikan oleh mana-mana institusi.

\section{RUJUKAN}

Abdul Rashid, Roswati, Isma Rosila Ismail, Radhiah Ismail dan Roslina Mamat, "Ketidaksantunan dalam Perbualan Bahasa Jepun oleh Pemandu Pelancong Malaysia," GEMA Online Journal of Language Studies 17, no. 3, (2017): 86-105.

Abdul Rashid, Roswati, Radhiah Ismail, Noor Asliza Abdul Rahim dan Roslina Mamat, "Humor dan Komunikasi Dalam Industri Pelancongan di Malaysia," Jurnal Komunikasi: Malaysian Journal of Communication 33, no. 1, (2017): 184-198.

Abdul Rashid, Roswati, Roslina Mamat, Hazlina Abdul Halim dan Normaliza Abdul Rahim, "Masyarakat Jepun Dalam Pelancongan: Satu Penelitian Budaya," Jurnal Komunikasi: Malaysian Journal of Communication 29, no. 2, (2013): 87-106.

Abdul Rashid, Roswati, "Strategi Komunikasi Bahasa Jepun dalam Konteks Antara Budaya Semasa Sesi Lawatan Pemanduan Pelancongan di Malaysia," (Tesis PhD, Universiti Putra Malaysia, 2015).

Hashiuchi, T., “Diskoosu: Danwa no orinasu sekai,” (Tokyo, Kuroshio Shuppan, 1999).

Haugh, Michael, "Utterance-final Conjunctive Particles and Implicature in Japanese Conversation," Pragmatics 18, no. 3, (2008): 425-451.

Isao, Iori, Takanashi Shino, Nakanishi Kumiko, and Yamada Toshihiro. "Shokyuu o oshieru hito no tameno Nihongo bunpoo handobukku", (Tokyo, 3A Corporation, 2000).

Mamat, Roslina, "Analisis Perbualan Penutur Asli Bahasa Jepun: Satu Kajian Pengambilan Giliran dan Aizuchi," (Tesis PhD, Universiti Malaya, 2004).

Mamat, Roslina, Normaliza Abdul Rahim, Hazlina Abdul Halim dan Farah Tajuddin, "Short Utterances in Japanese Language Conversation among Japanese and Malaysian Tourist Guides," Jurnal Komunikasi: Malaysian Journal of Communication 28, no. 1, (2012): 97-106.

Mamat, Roslina, Hazlina Abdul Halim dan Normaliza Abd Rahim, "Celahan dalam Perbualan Pemandu Pelancong Malaysia dan Pelancong Jepun," GEMA Online Journal of Language Studies 12, no. 3, (2012): 849-863.

Namiko, Abe, "The Meaning of '-N Desu' in Japanese," ThoughtCo., 29 Jun 2019, https://www.thoughtco.com/what-is-n-desu-2027871.

Nobuko, Mizutani, "Aizuchito Outou," in Mizutani Osamu ed., Hanashi Kotobano Hyougen, (Tokyo, Chikuma Shobo, 1983): 37-44.

Parsons, Rachel, "Statistics Solutions. What is Ethnography?", Complete Dissertation by Statistic Solutions, 15 August 2019, https://www.statisticssolutions.com/what-is-ethnography/.

Sacks, Harvey, Emanual Schegloff, and Gail Jefferson, "A Simplest Systematic for the Organization of TurnTaking for Conversation," Language 50, no. 4, (1974): 696-735.

Saft, Scott, "Exploring Aizuchi as Resources in Japanese Social Interaction: The Case of a Political Discussion Program," Journal of Pragmatics 39, no. 7, (2007): 290-1312.

Saji, Keizou, "Shuujoshino Kinou," Kokugo Kokubun 26, no. 7, (1956): 23-31.

Tanaka, Hiroko, "Turn Projection in Japanese Talk-in-Interaction," Research on Language and Social Interaction 33, no. 1, (2000): 1-38.

Takeuchi, T., "Disukoosu", (Tokyo, Kuroshio, 1999).

Tofugu, "What is n desu?" Tofugu.Com., 2007, https://www.tofugu.com/japanesegrammar/explainatory-formndesu/,2007. 